\title{
Prevalence of Pathogenic Bacteria in Open Drains and its Public Health Implications for Water Resources in Port Harcourt, Southern Nigeria David N Ogbonna* and Blessing A Erheriene
}

Department of Microbiology, Rivers State University, Nkpolu-Oroworukwo, PMB 5080, Port Harcourt, Nigeria

\begin{abstract}
Wastewater and sediment samples from the open drains along the Ntanwogba creek were collected from five (5) different sites and analyzed for the presence of pathogenic bacteria. Microbiological studies involved the isolation and characterization of isolates by assessing the gene/nucleotide structure of the bacterial community through the polymerase chain reaction study. Results of the analysis show that the following bacteria were identified from the samples. The gram-negative bacteria include, Proteus mirabilis M18, Klebsiella pneumoniae strain DSM 30104 Burkolderia multivorans strain AUO, Plesiomonas shigelloides strain 187-907R, Pseudomonas fluorescens strain PF1, Esherichia coli, Enterobacter asburiae strain TYP8, Proteus mirabilis M19, Pseudomonas nitroreducens strain LBQSKN1, while gram-positive bacterium was Bacillus ginsengisoli strain A1Cr. Results obtained showed that both wastewater and sediment samples had higher microbial counts from the various sampling sites. Excess untreated wastewater can run off or percolate down to groundwater, causing contamination of drinking water supplies with faecal wastes and other pollutants which may contribute significantly to the spread of diseases amongst our population. This shows that the wastewater effluents and the receiving water bodies could pose a potential health risk to the surrounding communities who depend on these water resources for various domestic activities.
\end{abstract}

Keywords: Pathogenic bacteria; Open drains; Diseases; Wastewater; Sediment samples

\section{Introduction}

Wastewater is a potential source of many human pathogenic bacteria which poses a serious health risk to the general public. When wastewater percolate into the soil, the transport of pathogenic bacteria from surface water to ground water increases the vulnerability of ground water [1], which is the source of drinking water in many parts of the world. This contributes significantly to the spread of diseases such as cholera, diarrhoea, dysentery, malaria and typhoid fever [26]. The Ntanwogba creek is an open drainage system with beehive of socio- economic activities around it. The anthropogenic activities within the areas covered by this creek may result in pollution of water resources through improper disposal of wastes in such drains [7]. These wastes may occur in solid or liquid forms consisting of organic and inorganic wastes, spent oil or lubricants, pesticides and fertilizers, stormwater, runoffs from flash floods, erosion or water from car garages and cleaning centers. The solid wastes such as bottles, cans, plastics and other household products may result in blockage of drains $[8,9]$. However, it is a common knowledge that poorly drained storm water forms a stagnant pool that provides breeding sites for disease vectors, causes pollution and stench in such places, thus defacing the aesthetic value of our environment [10-13]. As a result of poor network of drainages, water runs over the ground during rainstorms, picks up faeces and contaminates water resources.

Incidences of water-borne diseases in Nigeria urban areas leading to millions of death have been reported. Some of these deaths have been traced to the use of waters grossly polluted by untreated waste [14]. Epidemiological records in the Niger Delta, Nigeria also reveals the prevalence of water-borne diseases such as diarrhea, dysentery, typhoid etc. [15,16] cases of water borne diseases representing $20.24 \%$ of all cases in Ughelli, Delta state, Nigeria was traced to pollution of water resources through poor sanitation and improper disposal of wastes. These reported cases are attributed to high water table and high probability of groundwater contamination with faecal wastes coupled with poor waste management techniques and disposal problems in the Southern part of Nigeria $[17,18]$. Microbes may travel with the plume of percolating water from the open drains and contaminate the drinking water sources. This water may seep to the land surface, runoff into surface water or flow directly into the water table to cause contamination. Most worrisome is the crude manner in which wastes are evacuated and disposed of in haphazard manner into bodies of water, streams, open spaces and drainage channels or even composited and used as fertilizer. The practice leaves much to be desired because the seepage of the liquid content of the waste materials carries feacal materials and other pollutants into the groundwater bodies. Unfortunately the high porosity and permeable nature of the subsurface geologic formation and the shallow nature of water table of the Niger Delta region make the ground water bodies highly vulnerable to these pollutants and subsequent exposure of residents to associated dangers and eventually disease outbreaks [4,15,19-22]. Eventually leachates from these wastes find its way into boreholes, lakes, wells and other water bodies. The consequence is that, water quality is highly affected which becomes highly dangerous $[16,20]$. This study therefore was undertaken to identify some pathogenic bacteria associated with open drains and their potentials for disease outbreaks especially when they percolate in ground water resources due to inadequate waste management practices.

\section{Materials and Methods}

\section{Description of area of study}

The Ntanwogba creek is located on the western flank of Port

*Corresponding author: Ogbonna DN, Department of Microbiology, Faculty of Science, Rivers State University, Nkpolu-Oroworukwo, PMB 5080, Port Harcourt, Nigeria, Tel: +234-7061103614; E-mail: ogbonna.david@ust.edu.ng

Received September 08, 2017; Accepted September 12, 2017; Published September 19, 2017

Citation: Ogbonna DN, Erheriene BA (2017) Prevalence of Pathogenic Bacteria in Open Drains and its Public Health Implications for Water Resources in Port Harcourt, Southern Nigeria. Int J Waste Resour 7: 303. doi: 10.4172/22525211.1000303

Copyright: (c) 2017 Ogbonna DN, et al. This is an open-access article distributed under the terms of the Creative Commons Attribution License, which permits unrestricted use, distribution, and reproduction in any medium, provided the original author and source are credited. 
Harcourt City of Rivers State, Nigeria. The stream lies between latitude $4050 "$ and $5000 " \mathrm{~N}$, and longitude 6055 " and 7000 "E. According to Gobo et al. [23], the climate of the area is that of tropical equatorial latitude with rainfall occurring almost all year round. As one of the coastal states of Nigeria, it has one of the highest average rainfalls. The flat estuarine terrain and impermeable alluvial soil make drainage difficult. The Ntanwogba creek is a black water stream with its water source which runs through Orazi forest of Rumueme town across Abacha Road, Cherubim Road, Olu-Obasanjo Road, Okija Road and Afam Street (D/line), and meanders through the densely populated city of Port Harcourt into the Upper Bonny Estuary.

\section{Collection of samples}

Wastewater samples were collected from open drains along the Ntanwogba creek with sterilized plastic bottles collected from the University Microbiology Department. Each sample bottle was rinsed with the appropriate sample before the final collection according to the standard methods [24]. To collect the water sample, base of the sterilized sample bottle was held with one hand, plunged about 30 $\mathrm{cm}$ below the water surface with the mouth of the sample container positioned in an opposite direction to water flow [24]. The container was filled with wastewater samples from different locations starting from the upstream (Afam /Kaduna street behind the Winners chapel) to the downstream (at Abacha road, all sites in Port Harcourt, Rivers State Nigeria ) leaving a gap of about $2 \mathrm{~cm}$ and then covered. Sediment samples for analysis were also collected along the same water course. To collect the sediment samples, the bottles were opened and held with the left hand while using the right hand with a plastic scooper to scoop the sediment sample. The sample bottles were filled with sediment sample and covered immediately. After collection, the sample was immediately labelled and transported in a cooler packed with ice blocks for analysis. Sample collection was carried out from the month of February to June, twice monthly from March to August 2016.

\section{Microbiological analyses}

Serial dilution: Ten-fold serial dilutions of the samples were made according to the methods described by Oliveira et al. [25]

\section{Inoculation and incubation}

One millilitre of appropriate ten-fold serial dilution were inoculated onto appropriate surface dried Nutrient agar, Blood agar, CLED agar, MacConkey agar and Salmonella-Shiegella agar in triplicates using the pour plate and spread plate methods. Colonies which developed on the plates were counted and recorded using colony forming unit of the sample [26-28]. Inoculated plates were incubated at $37^{\circ} \mathrm{C}$ for 24 hours.

\section{Maintenance of pure culture}

Bacteria grown on Nutrient agar, Blood agar, Cystine lactose electrolyte deficient agar, MacConkey agar and Salmonella-Shigella agar were purified by repeated sub-culture onto nutrient agar media. Pure cultures were inoculated on Nutrient agar slants and incubated at $37^{\circ} \mathrm{C}$ for 24 hours, and then preserved in the refrigerator at about $4^{\circ} \mathrm{C}$ for further tests.

\section{DNA extraction and quantification}

For identification, the chromosomal DNA of each isolate was extracted using a ZR fungal/bacterial DNA mini preparation extraction kit supplied by Inqaba South Africa according to the manufacturer's instructions.

\section{Lysis of cells}

One thousand microlitres of 24 hours old luria bertani culture containing bacterial isolates were introduced into ZR bashingbead lysis tubes and centrifuged at $14000 \mathrm{xg}$ for 2 minutes to concentrate the cells. The supernatant was decanted and the procedure repeated. A heavy growth of bacterial isolates was suspended in $200 \mu \mathrm{l}$ of isotonic buffer into ZR Bashing Bead lysis tubes, $750 \mu \mathrm{l}$ of lysis solution was added to the tube. The tubes were secured in a bead beater (Gene disruptor) fitted with a $2 \mathrm{ml}$ tube holder assembly and processed at maximum speed for 8 minutes. The ZR bashingbead lysis tube was centrifuged at $10000 \mathrm{xg}$ for 1 minute $[29,30]$.

\section{Removal of contaminants}

Using a collection tube $400 \mu \mathrm{l}$ of supernatant was transferred to Zymo-Spin IV filter and centrifuged at $7000 \mathrm{xg}$ for 1 minute. In the collection tube $1200 \mu \mathrm{l}$ of ZR fungal/bacterial DNA binding buffer was added to the filtrate bringing the final volume to $1600 \mu \mathrm{l}, 800 \mu \mathrm{l}$ was then transferred to a Zymo-Spin IIC column in a collection tube and centrifuged at $10000 \mathrm{xg}$ for 1 minute, from the collection tube the flow through was discarded. The remaining $800 \mu \mathrm{l}$ was transferred to the same Zymo-Spin IIC column and spun. In a new collection tube $200 \mu \mathrm{l}$ of the DNA Pre-wash buffer was added to the Zymo-Spin IIC column and spun at $10000 \mathrm{xg}$ for 1 minute [31].

\section{Recovery of DNA}

To elute the DNA, the Zymo-Spin IIC column was transferred to a clean $1.5 \mu \mathrm{l}$ centrifuge tube, $100 \mu \mathrm{l}$ of DNA elution buffer was added to the column matrix and centrifuged at $10000 \mathrm{xg}$ for 30 seconds. Using Nanodrop 1000 spectrophotometer the extracted DNA was quantified and the ultra-pure DNA was stored at $-20^{\circ} \mathrm{C}$ for other downstream reaction.

\section{PCR amplification of $16 \mathrm{~S}$ ribosomal RNA}

The 16S ribosomal RNA (rRNA) of the bacterial isolates was amplified using the polymerase chain reaction (PCR) technique in which two universal primers: forward primer $27 \mathrm{~F}$ (5'-AGAGTTTGATCMTGGCTCAG-3') and reverse primer 1492R (5'-CGGTTACCTTGTTACGACTT-3') were used incorporated into the PCR mix. The mix included: the $\mathrm{x} 2$ dream taq master mix (taq polymerase, DNTPs, $\mathrm{MgCl}$ ) supplied by Inqaba, South Africa, the primers at a concentration of $0.4 \mathrm{M}$ and the extracted DNA as template. The following PCR conditions were used: Initial denaturation at $95^{\circ} \mathrm{C}$ for 5 minutes; denaturation at $95^{\circ} \mathrm{C}$ for 30 seconds; annealing at $52^{\circ} \mathrm{C}$ for 30 seconds; extension at $72^{\circ} \mathrm{C}$ for 30 seconds in 35 cycles and final extension at $72^{\circ} \mathrm{C}$ for 5 minutes. The PCR product was confirmed by electrophoresis on $1 \%$ agarose gel at $120 \mathrm{~V}$ for 15 minutes and visualized on UV trans-illuminator.

Sequencing was done at Inqaba Biotechnological, Pretoria South Africa using the BigDye terminator kit on a $3510 \mathrm{ABI}$ sequencer. With the bioinformatics algorithm trace edit the obtained sequences were edited and similar sequences were downloaded from the National Centre for Biotechnology Information (NCBI) database using BLASTN.

\section{Results and Discussion}

Using molecular identification method, a total of ten (10) bacterial species were identified from the different sampling stations. The bacterial species were identified as Bacillus ginsengisoli strain A1Cr, Proteus mirabilis M18, Klebsiella pneumoniae strain DSM 30104, Burkolderia multivorans strain AUO, Plesiomonas shigelloides 
Citation: Ogbonna DN, Erheriene BA (2017) Prevalence of Pathogenic Bacteria in Open Drains and its Public Health Implications for Water Resources in Port Harcourt, Southern Nigeria. Int J Waste Resour 7: 303. doi: 10.4172/2252-5211.1000303

strain 187-907R, Pseudomonas fluorescens strain PF1, Esherichia coli, Enterobacter asburiae strain TYP8, Proteus mirabilis M19, Pseudomonas nitroreducens strain LBQSKN1 as shown in Figure 1. This study first employed culture-based techniques which gives an indication of the general microbial profile of the water body that was sampled in this study, molecular techniques offer more sensitivity and specificity than culture-based techniques. In the present study, genomic DNA of randomly selected isolates from various samples was subjected to the conventional PCR-based technique using species-specific primers in order to confirm the presence of the target organisms in the effluent and receiving water sample. Microorganisms have been described as ubiquitous and according to Coleman et al. [32] their presence particularly in an aquatic environment rely on the nutrient compound being added during natural storm water run offs as well as soil erosion and discharge from sewage effluents.

Similarly, organisms such as: Bacillus sp., Esherichia coli, Enterobacter sp., Proteus mirabilis, Klebsiella pneumonia and Pseudomonas sp., have been isolated from different water bodies and dump sites [33-37]. However Okija and Olu-Obasanjo sampling stations had the highest number of bacterial isolates from both sediment and water samples, which could be due to the fact that the area is full of socioeconomic activities than the other three stations (Table 1). In the sediments, Bacillus ginsengisoli occurred more in Abacha and Olu-Obasanjo stations with a percentage occurrence of $17 \%$ and $16 \%$ respectively while in the wastewater Proteus mirabilis M19 and Proteus mirabilis M18 had the highest frequency of occurrence of $15 \%$ and $13 \%$ respectively for Okija and Olu-Obasanjo stations. Pseudomonas nitroreducens had $15 \%$ in sediments for Afam street while Burkolderia multivorans had the least frequency of occurrence of $2 \%$ and $4 \%$ for wastewater samples. However, Microorganisms are known for essential functions which include decomposition of organic materials, bioaccumulation of chemicals and biogeochemical cycling of elements. Their presence, abundance and growth in the environment are greatly influenced by factors such as $\mathrm{pH}$, temperature, pressure, availability of nutrients and salinity [38]. These pathogens might threaten public health by migrating into ground water or surface water to transmit diseases [6,39-42]. Bacteria from wastewater can be discharged into water columns which are subsequently absorbed to sediments, and when the bottom stream is disturbed, the sediment releases the bacteria back into the water columns presenting long term health hazards [4345]. In Rivers state, wastes generated from various anthropogenic activities are channeled directly into the tributaries of the River through open drainage channels. This act could introduce enteric pathogens e.g. Bacillus sp., Escherichia sp., etc. and excess nutrients into the river, resulting to eutrophication $[46,47]$. The consequences of such anthropogenic pollution during various socio economic activities can lead to the transmission of diseases by water borne pathogens, eutrophication of water bodies, accumulation of toxic or recalcitrant chemicals in the soil, destabilization of ecological balance and negative effects on human health $[45,48]$.

The rate of growth of bacterial counts/ species were more in sediments than in wastewater samples (Table 2). Sediment samples for Okija and Olu-Obasanjo road had $2.2 \times 10^{7} \mathrm{cfu} / \mathrm{g}$ and $2.1 \times 10^{7} \mathrm{cfu} / \mathrm{g}$ respectively while Cherubim road had the least of $1.3 \times 10^{7} \mathrm{cfu} / \mathrm{g}$. For wastewater samples, Abacha road had $2.3 \times 10^{6} \mathrm{cfu} / \mathrm{ml}$ while Cherubim road also had the least with $1.0 \times 10^{6} \mathrm{cfu} / \mathrm{ml}$ (Table 2). The results of this study shows that the presence of these pathogenic bacteria in such environments can affect human health, causing various diseases from allergic reaction to more serious systemic infections. Their presence in wastewater indicates that there could be possible contamination of water resources $[25,49]$ which may be responsible for the degradation and pollution of receiving water bodies. Their presence in these drainage

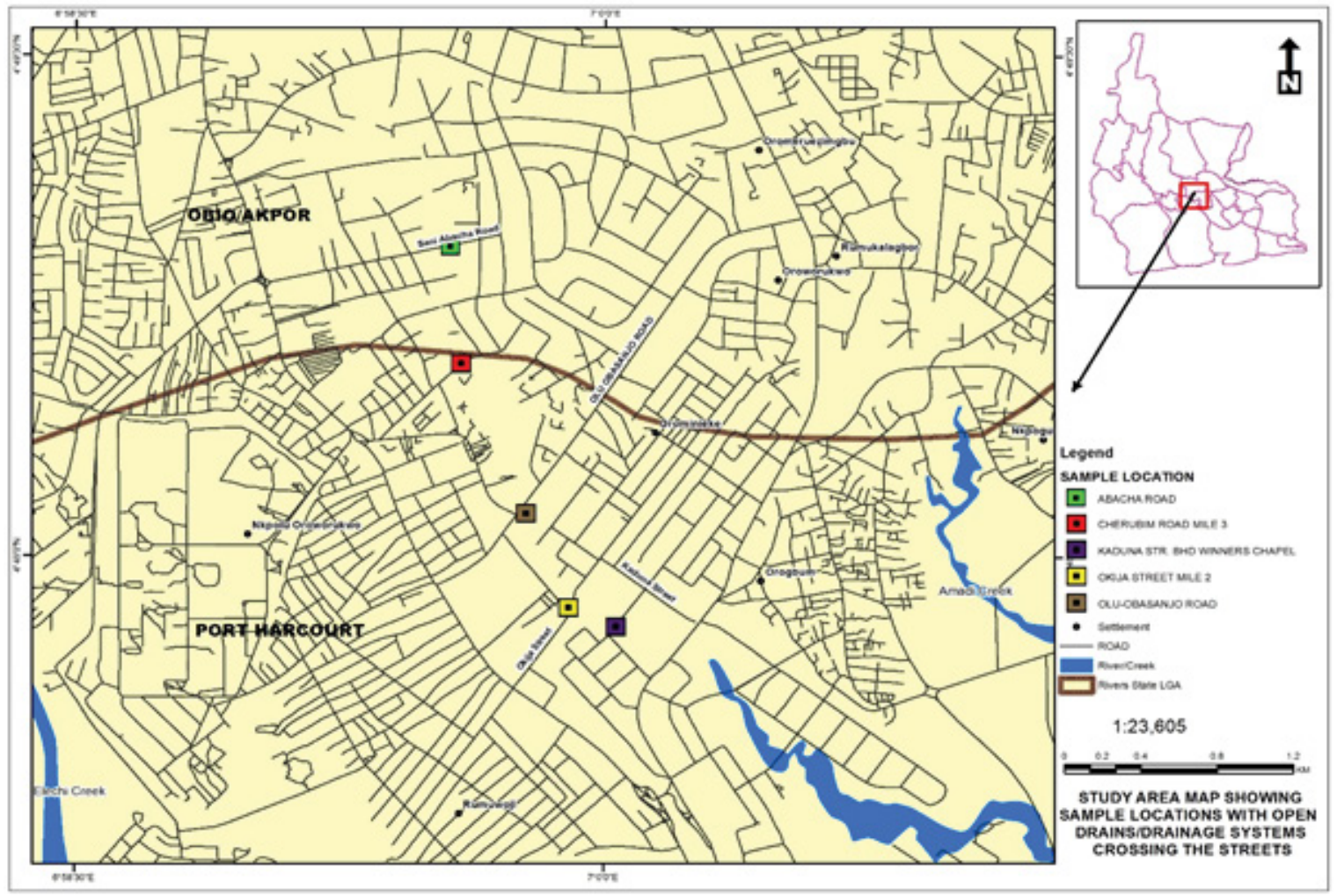

Figure 1: Map of Port Harcourt showing sampling stations along the Ntanwogba creek. 
Citation: Ogbonna DN, Erheriene BA (2017) Prevalence of Pathogenic Bacteria in Open Drains and its Public Health Implications for Water Resources in Port Harcourt, Southern Nigeria. Int J Waste Resour 7: 303. doi: 10.4172/2252-5211.1000303

Page 4 of 6

\begin{tabular}{|c|c|c|c|c|c|c|c|c|c|c|}
\hline \multirow{2}{*}{ Organisms } & \multicolumn{2}{|c|}{ Abacha Road } & \multicolumn{2}{|c|}{ Afam Street } & \multicolumn{2}{|c|}{ Cherubim Road } & \multicolumn{2}{|c|}{ Okija Road } & \multicolumn{2}{|c|}{ Olu-Obasanjo Road } \\
\hline & Sediment & Wastewater & Sediment & Wastewater & Sediment & Wastewater & Sediment & Wastewater & Sediment & Wastewater \\
\hline $\begin{array}{l}\text { Bacillus } \\
\text { ginsengisoli }\end{array}$ & $19(17 \%)$ & $24(14 \%)$ & $18(14 \%)$ & $24(11 \%)$ & $20(15 \%)$ & $29(14 \%)$ & $20(14 \%)$ & $27(12 \%)$ & $21(16 \%)$ & $30(14 \%)$ \\
\hline $\begin{array}{l}\text { Proteus mirabilis } \\
\text { M18 }\end{array}$ & $13(12 \%)$ & $18(11 \%)$ & $11(9 \%)$ & $23(11 \%)$ & $16(12 \%)$ & $22(10 \%)$ & $17(12 \%)$ & $29(13 \%)$ & $14(10 \%)$ & $29(13 \%)$ \\
\hline $\begin{array}{l}\text { Klebsiella } \\
\text { pneumoniae }\end{array}$ & $6(6 \%)$ & $11(7 \%)$ & $11(9 \%)$ & $17(8 \%)$ & $6(5 \%)$ & $9(4 \%)$ & $7(5 \%)$ & $14(6 \%)$ & $9(7 \%)$ & $15(7 \%)$ \\
\hline $\begin{array}{l}\text { Burkolderia } \\
\text { multivorans }\end{array}$ & $2(2 \%)$ & $8(5 \%)$ & $3(2 \%)$ & $9(4 \%)$ & $3(2 \%)$ & $8(4 \%)$ & $5(3 \%)$ & $11(5 \%)$ & $4(3 \%)$ & $9(4 \%)$ \\
\hline $\begin{array}{l}\text { Plesiomonas } \\
\text { shigelloides }\end{array}$ & $13(12 \%)$ & $19(11 \%)$ & $16(13 \%)$ & $23(11 \%)$ & $17(13 \%)$ & $24(11 \%)$ & $21(14 \%)$ & $25(11 \%)$ & $11(8 \%)$ & $23(10 \%)$ \\
\hline $\begin{array}{l}\text { Pseudomonas } \\
\text { fluorescens }\end{array}$ & $10(9 \%)$ & $14(8 \%)$ & $16(12 \%)$ & $21(11 \%)$ & $16(12 \%)$ & $23(11 \%)$ & $18(12 \%)$ & $23(10 \%)$ & $17(13 \%)$ & $21(10 \%)$ \\
\hline Esherichia coli & $14(13 \%)$ & $19(11 \%)$ & $12(9 \%)$ & $22(11 \%)$ & $12(9 \%)$ & $25(12 \%)$ & $11(8 \%)$ & $27(12 \%)$ & $12(9 \%)$ & $23(10 \%)$ \\
\hline $\begin{array}{l}\text { Enterobacter } \\
\text { asburiae }\end{array}$ & $8(7 \%)$ & $16(10 \%)$ & $10(8 \%)$ & $22(10 \%)$ & $9(7 \%)$ & $16(8 \%)$ & $8(5 \%)$ & $11(5 \%)$ & $11(8 \%)$ & $15(7 \%)$ \\
\hline $\begin{array}{l}\text { Proteus mirabilis } \\
\text { M19 }\end{array}$ & $13(12 \%)$ & $20(12 \%)$ & $12(9 \%)$ & $25(12 \%)$ & $13(10 \%)$ & $27(13 \%)$ & $19(13 \%)$ & $33(15 \%)$ & $17(13 \%)$ & $28(13 \%)$ \\
\hline $\begin{array}{l}\text { Pseudomonas } \\
\text { nitroreducens }\end{array}$ & $11(10 \%)$ & $19(11 \%)$ & $19(15 \%)$ & $24(11 \%)$ & $18(14 \%)$ & $28(13 \%)$ & $21(14 \%)$ & $25(11 \%)$ & $19(14 \%)$ & $25(11 \%)$ \\
\hline
\end{tabular}

Note: Values in parenthesis represent percentage of occurrence.

Table 1: Distribution of bacterial isolates from all stations.

\begin{tabular}{|l|l|l|l|}
\hline S/N & Stations & Sediment (cfu/g) & Wastewater (cfu/ml) \\
\hline 1. & Abacha Road & $1.4 \times 10^{7}$ & $2.3 \times 10^{6}$ \\
\hline 2. & Afam Street & $2.0 \times 10^{7}$ & $2.2 \times 10^{6}$ \\
\hline 3. & Cherubim Road & $1.3 \times 10^{7}$ & $1.0 \times 10^{6}$ \\
\hline 4. & Okija Street & $2.2 \times 10^{7}$ & $1.1 \times 10^{6}$ \\
\hline 5. & Olu-Obasanjo Road & $2.1 \times 10^{7}$ & $2.3 \times 10^{6}$ \\
\hline
\end{tabular}

Table 2: Total heterotrophic count of bacterial isolates from samples (cfu/ml) from various sampling stations.

channels may most likely come through the runoff of fertilizers or sewage which contain excess nutrient that plants and microorganisms can utilize for growth. Also, their abundance and activities in drainage systems have profound effect on the physicochemical characteristics of the wastewater especially at the banks of the creek and possibly when the wastewater percolate into other water resources (Figure 2).

\section{Conclusion}

This study observed that water samples from the open drainage channels were copiously polluted with human and animal faeces, as well as uncontrolled sewage discharges which contains microorganisms. Other non-point sources of pollution such as agricultural pollutants from surrounding localities enter the scarce water resources to cause pollution [50,51]. This is exacerbated due to continuous population growth, industrialization and urbanization giving rise to increased socioeconomic activities. The implication is that water sources are polluted which can cause deadly diseases among the informal settlement dwellers [52]. Most of these diseases are transmitted to humans through the ingestion of contaminated water and foods [50]. Most worrisome is that communities who live at the banks around these open drainage channels and rivers do not only dispose domestic wastes into the drains but still practice open defaecation and rely on public sanitation facilities which are inadequate to sustain healthy environment. Pathogens associated with these poor sanitation may result to an outbreak of diarrhea. Diarrhoea is described as the second leading contributor to global burden of disease ahead of heart disease and HIV/AIDS and it is estimated that diarrhea causes $25-75 \%$ childhood illnesses and deaths in Africa [53,54]. Therefore, effective protection of water resources from the impacts of wastewater disposal

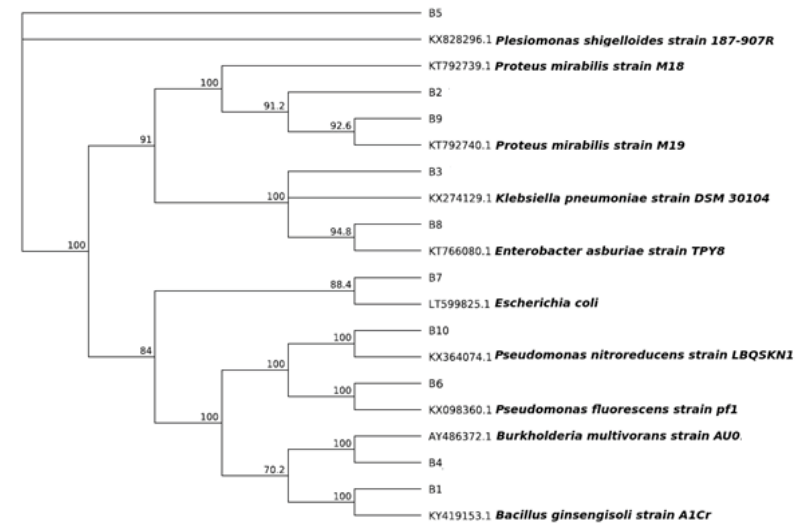

Figure 2: Phylogenetic tree showing evolutionary relationship between the bacterial isolates.

and other pollutants into open drainage channels is a matter of concern. Government is therefore advised to provide basic services such as safe drinking water and improved sanitation infrastructures as efforts to prevent illnesses and deaths amongst our population due to waterborne pathogens, especially to everyone who relies on direct use of effluent discharge into watercourses.

\section{References}

1. Jin Y, Flury M (2002) Fate and transport of viruses in porous media. Adv Agron 4: 39-102. 
Citation: Ogbonna DN, Erheriene BA (2017) Prevalence of Pathogenic Bacteria in Open Drains and its Public Health Implications for Water Resources in Port Harcourt, Southern Nigeria. Int J Waste Resour 7: 303. doi: 10.4172/2252-5211.1000303

Page 5 of 6

2. Van P Pur A (1990) The importance of clean water to industries in developed world ( $4^{\text {th }}$ edn.). Grovener Press, Hong Kong

3. Bicki T (2001) Onsite sewage disposal: The influence of system density on water quality. J Environmental Health 53: 39-42.

4. Burubai W, Akor AJ, Lilly MT (2007) Performance evaluation of a septic system for high water-table areas. American Eurasian Journal of Scientific Research 2: $112-116$.

5. Ochuko U, Thaddeus O (2013) Effect of underground on-site sewage disposal system on the quality of water from hand dug wells in the urban Centre of Ughelli, Delta State, Nigeria. Stand J Educ Res Essay 1: 81-90.

6. Ogbonna DN (2014) Distribution of microorganisms in water, soils and sediment from abattoir wastes in Southern Nigeria. Int J Curr Microbiol Appl Sci 3: 11831200

7. Ogbonna DN, Chilaka SN, Gobo AE, Amangabara GT (2008) Effect of waste disposal practices and perennial flooding in Port Harcourt Metropolis, Nigeria. Int J Res Biosciences 4: 103-110.

8. Ogbonna DN, Amangabara GT, Ekere TO (2007) Urban solid waste generation in Port Harcourt Metropolis and its implication for waste management. Management of Environmental Quality: An International Journal 18: 71-88.

9. Ogbonna DN (2017) Public health implications of pathogenic fungi isolated from open drains in Port Harcourt. Int J Pharm Sci Res 3: 24-33.

10. Ekugo El (1998) Public health and urban sanitation.

11. Aibor EJ, Olorunda JO (2006) A technical handbook of environmental health in the $21^{\text {st }}$ Century for professionals and students.

12. Ifeoma, M, Nkiru E (2009) Public health implication of household solid waste management in Awka South East Nigeria. The Internet Journal of Public Health 1: 1

13. Owaduge S (2010) Solid waste management in Lokoja metropolis.

14. UNEP (2005) Freshwater pollution.

15. Ochuko U, Thaddeus O (2013) Effect of underground on-site sewage disposal system on the quality of water from hand dug wells in the urban Centre of Ughelli, Delta State, Nigeria. Stand J Educ Res Essay 1: 81-90.

16. Mogborukor JOA (2012) Domestic sewage disposal and Quality of wate from hand dug wells in Ughelli, Nigeria. An International Journal of Science \&Technology 1: 112-125.

17. Ogbonna DN Ekweozor IKE, Igwe FU (2002) Waste Management, a tool for environmental protection in Nigeria. Ambio 31: 55-57.

18. Ogbonna DN, Idam DY (2007) Appropriate sanitation systems for low - income coastal and waterfront communities in the Niger Delta. J Appl Sci 7: 1116-1123.

19. Plummer CC, McGeary D (1993) Physical geology.

20. Obasi RA, Balogun O (2001) Water quality and environmental impact assessment of water resources in Nigeria. Afr J Environ Stu 2: 232-235.

21. Omuta GED (1999) Towards a sustainable environmental culture in Nigeria daily sketch.

22. Tamunobereton-ari I, Uko ED, Horsfall OI (2013) Correlational analysis of sewage disposal methods and incidence rates of typhoid fever and cholera in Port Harcourt metropolis, Nigeria. Journal of Emerging Trends in Engineering and Applied Sciences 4: 16-23.

23. Gobo AE, Ubong IU, Ede PN (2008) Relationship between rainfall trends and flooding in the Niger-Benue river basins.

24. APHA (American Public Health Association; American Water Works Association (AWWA); Water Environmental Federation (WEF) (2012) Standard methods for the examination of water and wastewater (22nd edn.)

25. Oliveira HMB, Santos C, Russell R, Paterson M, Gusmão NB, et al. (2016) Fungi from a groundwater-fed drinking water supply system in Brazil. Int J Environ Res Public Health 13: 304-315.

26. Lateef A. Oloke JK, Gueguim-Kana EB (2005) Prevalence of bacterial resistance in clinical, food, water and some environmental samples in Southwest Nigeria. Environ Monit Assess 100: 59-69.

27. Guo M, Yuan Q, Yang J (2013) Microbial selectivity of UV treatment on antibiotic-resistant heterotrophic bacteria in secondary effluents of a municipal wastewater treatment plant. J Water Res 47: 6388-6394.

28. Hussain T, Roohi A, Munir S, Ahmed I, Khan J, et al. (2013) Biochemical characteristics and identification of bacterial strains from drinking water sources of Kohat, Pakistan. Afr J Microb Res 7: 1579-1590.

29. Frostegard A, Courtois S, Ramisse V, Clerc S, Bernillon D, et al. (1999) Quantification of bias related to the extraction of DNA directly from soils. App Environ Microb 65: 5409-5420.

30. Kresk, M, Wellington EMH (1999) Comparison of different methods for the isolation and purification of total community DNA from soil. J Microb Methods 39: 1-16.

31. Miller DN, Bryant JE, Madsen EL, Ghiorse WC (1999) Evaluation and optimization of DNA extraction and purification procedures for soil and sediment samples. Appl Environ Microb 65: 4715-4724.

32. Coleman RN, Campbell JN, Cook FD, Westlake DWJ (1974) Urbanization and the microbial content of the North Saskatchewan River. Appl Microb 27: 93-101.

33. John IA, Debbie SS, Jon JC, Ramon JS (1981) Antibiotic-resistant bacteria in drinking water. Appl Environ Microb 42: 277-283.

34. Frederico MP, Augela MSP, Marcio CGS, Veronica DG, Paulo RB, et al. (2002) Ecological aspects of the antimicrobial resistance in bacteria of importance to human infection. Braz J Microbiol 33: 287-293.

35. Obire O, Wemedo SA (2002) Seasonal Effect on the bacterial and funga population of an oilfield wastewater-polluted soil in Nigeria. J Appl Sci Environ Manag 6: 17-21.

36. Odeyemi AT (2012) Antibiogram status of bacterial isolates from air around dumpsite of Ekiti State destitute Centre at llokun, Ado-Ekiti, Nigeria. J Microbio Res 2: 12-18.

37. Subhashree S, Kanti CC, Kumar BP (2012) In vitro antibacterial activities study of polymeric ciprofloxacin suspensions. International Research Journal of Pharmacy 3: 302-304.

38. Ogbonna DN, Ideria TJK (2014). Effect of abattoir on the physio-chemical characteristics of soil and sediment in Southern Nigeria. Journal of Scientific Research and Reports 3: 1612-1632.

39. Manson CF (1991) Biology of freshwater pollution (2nd edn.). Longman Scientific and Technical John Witey and Sons, New York.

40. Meadows R (1995) Livestock legacy. Environmental Health Perspective 103 1096-1100.

41. Gauri SM (2004) Characterization of effluent waste water from abattoirs for land applications. Food Reviews International 20: 229-256.

42. Raheem NK, Morenikeji OA (2008) Impact of abattoir effluents on surface waters of the Alamuyo stream in Ibadan. Journal of Applied Science and Environmental Management 12: 73-77.

43. Sherer BM, Ronald MJ, James AM, John CB (1992) Indicator bacterial survival in stream sediments. Environ Qual 21: 591-595.

44. Abu-Ashour J, Joy DM, Lee H, Whiteley HR, Zelin S (1994) Transport of microorganisms through soil. Water, Air and Soil Pollution 75: 141-158.

45. Nafarnda WD, Ajayi IE, Shawulu JC, Kawe MS Omeiza GK, et al. (2012) Bacteriological quality of abattoir effluents discharged into waterbodies in Abuja, Nigeria. International Scholarly Research Network.

46. Odeyemi O (1991) Consequences of water pollution by solid wastes and faecal materials in Nigeria.

47. Adeyemo OK, Ayodeji IO, Aiki-Raji CO (2002) The water quality and sanitary conditions in a major abattoir (Bodija) in Ibadan, Nigeria. Afr J Biomed Res 5 : $51-55$

48. Amisu KO, Coker AO, Isokphehi RD (2003) Arcobacter butzlieri strains from poultry abattoir effluent in Nigeria. East Afr Med J 80: 218-221.

49. Prescott LM, Harley J, Klein DA (2005). Drug resistance. In: Microbiology (6th edn.). McGraw Hill Higher Education, US. pp: 792-794.

50. Momba MNB, Osode AN, Sibewu M (2006) The impact of inadequate wastewater treatment on the receiving water bodies - Case study: Buffalo City and Nkonkobe Municipalities of the Eastern Cape Province. Water South Africa 32: 687-692.

51. Dungeni M, Van Der Merwe RR, Momba MNB (2010) Abundance of 
Citation: Ogbonna DN, Erheriene BA (2017) Prevalence of Pathogenic Bacteria in Open Drains and its Public Health Implications for Water Resources in Port Harcourt, Southern Nigeria. Int J Waste Resour 7: 303. doi: 10.4172/2252-5211.1000303

pathogenic bacteria and viral indicators in chlorinated effluents produced by four wastewater treatment plants in the Gauteng Province, South Africa. Water South Africa 36: 607-614.

52. Cabral JPS (2010) Water microbiology: Bacterial pathogens and water. Int $J$ Environ Res Public Health 7: 3657-3703.
53. Dewaal CS, Robert N, Witmer J, Tian XA (2010) A comparison of the burden of foodborne and waterborne diseases in three world regions. Food Protection Trends 30: 483-490.

54. Giorgis Z, Teklehaimanot GZ, Genthe B, Kamika I, Momba MNB (2015) Prevalence of enteropathogenic bacteria in treated effluents and receiving water bodies and their potential health risks. Sci Total Environ 518-519: 441-449 